\title{
Potential risk factors and triggers for back pain in children and young adults. A scoping review, part ll: unclear or mixed types of back pain
}

Amber M Beynon ${ }^{1 *}$ (D), Jeffrey J Hebert ${ }^{1,2}$, Charlotte Lebouef-Yde ${ }^{1,3}$ and Bruce F Walker ${ }^{1}$

\begin{abstract}
Background: Back pain is a global problem in terms of disability and financially, with a large burden both to the individual and to society. Back pain was previously believed to be uncommon in children. However, there is a growing body of evidence that this is not the case.

Objective: Part I of this scoping review studied risk factors of incident and episodic back pain. In this part II we aimed to identify all risk factors and triggers with unclear or mixed type back pain in young people and to identify any gaps in the literature.

Methods: A scoping review design was selected to summarise the evidence, as there are many studies on "risk factors" for back pain. The scoping review followed the PRISMSA-ScR guidelines. We considered all studies that tested potential risk factors and triggers for thoracic and/or lumbar spine pain, in children, adolescents, and young adults ( $\leq 24$ years). PubMed and Cochrane databases were searched from inception to September 2018, to identify relevant English language articles. The results regarding potential risk factors were separated into temporal precursors and bidirectional risk factors and the studies were classified by study design.

Results: Our comprehensive search strategy identified 7356 articles, of which 83 articles were considered eligible for this review (part II). There were 53 cross-sectional studies and 30 cohort studies. Potential risk factors for back pain were: female sex, older age, later pubertal status, positive family history of back pain, increased growth, and a history of back pain, most of which are temporal precursor variables. There was limited research for the illness factors, spinal posture, and muscle endurance in the development of back pain.

Conclusion: Many of the included studies approached risk factors in similar ways and found factors that were associated with back pain but were not obvious risk factors as causality was uncertain. Future research should be more rigorous and innovative in the way that risk factors are considered. This could be through statistical approaches including cumulative exposures, or longitudinal approaches including multi-trajectory methods. Additionally, data on proposed risk factors should be collected before the onset of back pain.
\end{abstract}

Keywords: "Risk factors", "Back pain", Children, Adolescent, Young adult, Scoping review

\footnotetext{
* Correspondence: amber.beynon@murdoch.edu.au

${ }^{1}$ College of Science, Health, Engineering and Education, Murdoch University,

90 South Street, Murdoch 6150, Western Australia, Australia

Full list of author information is available at the end of the article
}

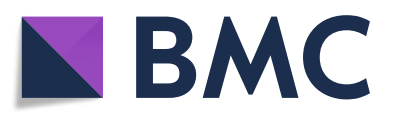

(c) The Author(s). 2019 Open Access This article is distributed under the terms of the Creative Commons Attribution 4.0 International License (http://creativecommons.org/licenses/by/4.0/), which permits unrestricted use, distribution, and reproduction in any medium, provided you give appropriate credit to the original author(s) and the source, provide a link to the Creative Commons license, and indicate if changes were made. The Creative Commons Public Domain Dedication waiver (http://creativecommons.org/publicdomain/zero/1.0/) applies to the data made available in this article, unless otherwise stated. 


\section{Background}

Back pain is a global problem in terms of disability and financial costs, with a large burden both to the individual and to society [1]. Back pain was once believed to be uncommon in young people. However there is evidence that this is not the case $[2,3]$. Back pain can start during childhood or adolescence $[2,3]$. Therefore, it is important not to ignore younger populations. Numerous studies have attempted to investigate a myriad of potential risk factors of back pain in children and young adults. Identifying early life factors that predispose young people to back pain in later life may help identify at-risk populations and inform future prevention strategies. Prevention of back pain in adolescence could help the prevention of back pain into adulthood [4].

Some potential risk factors definitely occur before the inception of the disease; we define these variables as temporal precursors. Temporal precursors are variables known to have a definite preceding temporal relationship with a disease (e.g., sex, age, pubertal status, family history, family socioeconomic factors, and height). Conversely, other factors studied may not have occurred prior to the onset of the disease, and they can have a bidirectional relationship with the disease of interest. If such potential risk factor is measured concurrently with back pain, then we cannot know if the potential risk factor preceded the back pain or not. Examples include body mass index (BMI), muscle endurance and flexibility, posture, physical activity behaviour, work, screen time, inadequate sleep, smoking, illnesses, and psychosocial factors.

Due to the vast number of studies on "risk factors" for back pain a two part scoping review of the literature was chosen as the best way to summarise the evidence. Part I of this scoping review (Potential risk factors and triggers for back pain in children and young adults. A scoping review, part I: incident and episodic back pain) studied risk factors of incident and episodic back pain. In Part II we aimed to identify all risk factors and triggers for back pain (unclear or mixed types of back pain) in young people and to identify any gaps in the literature. Moreover, in this second part, all eligible studies (unclear or mixed types of back pain) that tested potential risk factors of back pain and triggers of its further episodes were included.

\section{Methods}

The full methods are reported elsewhere (Potential risk factors and triggers for back pain in children and young adults. A scoping review, part I: incident and episodic back pain). However, a summary of the methods is provided below. We undertook a scoping review in accordance with reporting guidelines (PRISMA-ScR) [5]. A review protocol was not included in a registry as PROSPERO does not currently accept registrations for scoping reviews. The broad question of interest was what are the potential risk factors and potential triggers for back pain in childhood and young adulthood? 'Back pain' was defined as pain within the thoracic and/or lumbar areas. A search was conducted using the PubMed and Cochrane databases from inception to September 2018. The full search strategy is listed in Additional file 1. Results of the search were reported as per the PRISMA flow diagram (Fig. 1).

\section{Eligibility criteria}

We included studies that reported on potential risk factors or triggers for pain in the thoracic and/or lumbar spine (a risk factor is the cause of 'disease' of back pain defined as the first time they have back pain compared to a trigger, which could lead to an episode of back pain when the disorder of back pain is already established). The majority of the participants were to be less than 25 years old at baseline. The age classification is based on the MeSH definition of a young adult (19-24 years). Additionally, the contemporary definitions of adolescence includes young adulthood (10-24 years) [6]. Original peer-reviewed studies in the English language from any country of origin were included and study designs comprised retrospective, cross-sectional, and prospective observational studies. Cross-sectional studies were only included if the potential risk factors met Bradford Hill's tenet of temporality for the study of risk factors or triggers (i.e., if the exposure was classified as a temporal precursor e.g. age) [7].

\section{Study selection, data charting and synthesis of results}

Titles, abstracts, and full-text articles were screened by one researcher (AB) twice (March 2018 and then September 2018) against the inclusion criteria. The second search identified four additional articles due to the passage of time. Another researcher (BW) verified the study selection for accuracy (titles, abstracts, and full-text screen) and full consensus was met through discussion.

Calibration of the data charting forms was conducted by two researchers $(\mathrm{AB}$ and $\mathrm{CLY})$. One researcher $(\mathrm{AB})$ piloted the form on three studies. This process was verified by another researcher (CLY). This was an iterative process in which there were many changes during each round. Any disagreements were resolved by a third researcher (BW).

Charting of data (data extraction in scoping reviews [8]) was completed by one researcher $(\mathrm{AB})$ using the evidence tables. This information was checked for errors several times with an audit of all data entered with at least a week between each audit. Potential risk factors or triggers were separated into temporal precursors or potentially bidirectional risk factors. Results for the cross-sectional and prospective studies are reported together for potential risk factors that are inherently present before the back pain 


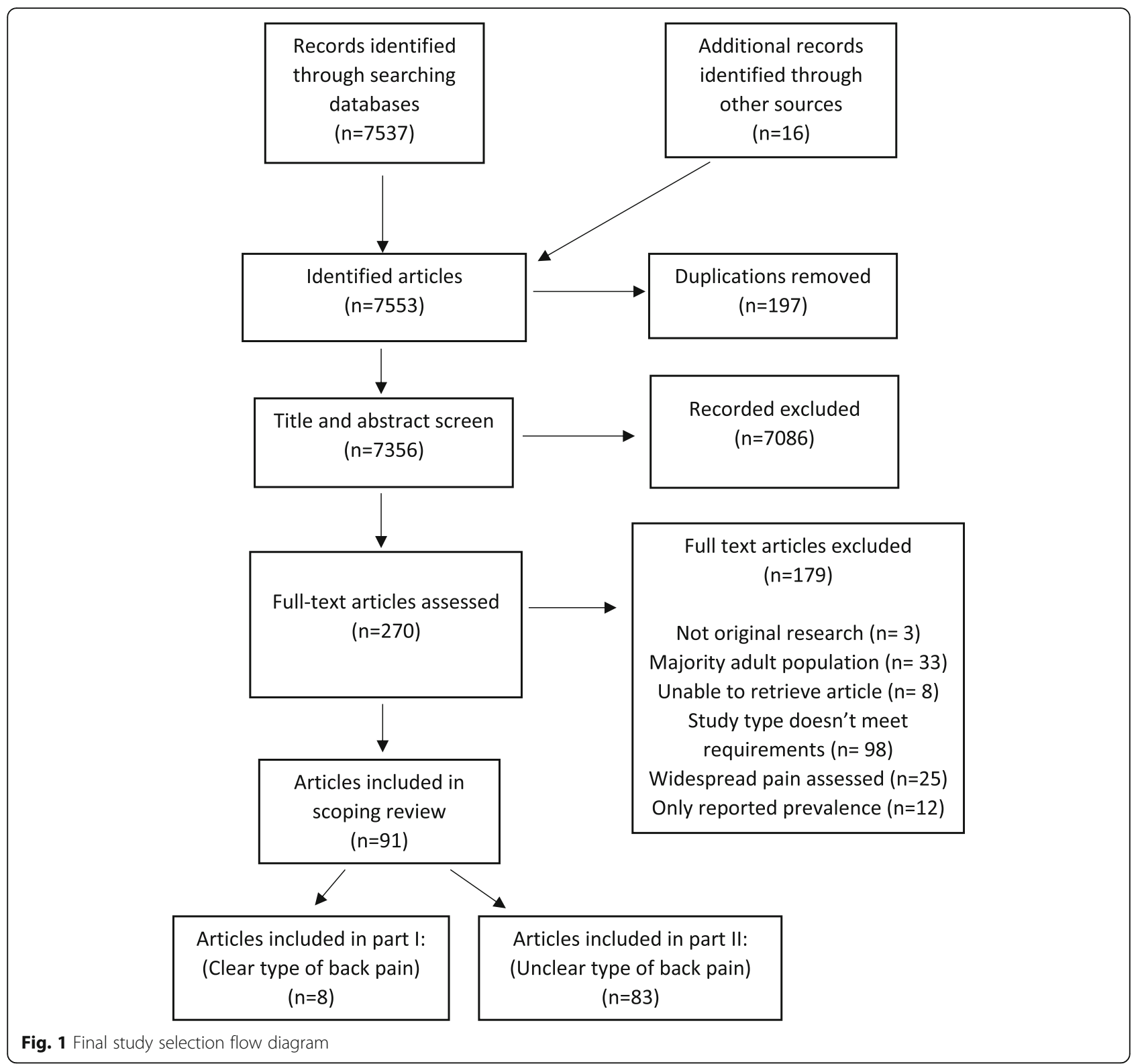

(temporal precursors). If a study had multiple estimates for the same risk factor the most adjusted estimate of association was extracted. Clarity of definition of back pain was assessed in each study with a summative score provided. Individual points were given if there was a clear description of the area of back pain, a clear reporting of the recall period, a clear definition of the type of back pain, and if there was an attempt to collect valid data (maximum four points).

\section{Results}

\section{Study selection}

Our database searches identified 7537 articles and a subsequent search of the relevant references lists resulted in an additional 16 articles. In all, 91 articles were considered eligible for this review. Eight studies appeared to have studied risk factors of incident back pain and back pain episodes (reported in part I). Within part II, 83 studies were included, as these failed to clearly identify whether they studied inception events or ongoing/episodes of back pain (Fig. 1).

\section{Study characteristics and synthesis of results}

Of the 83 articles included in this review, 30 (36\%) were prospective cohort studies [4, 9-37]. The majority of cohort studies did not have a clear description of back pain or captured a mixture of back pain types. Thus, many studies appear to have dealt with either back pain episodes or the incidence of back pain. They only 
considered a limited time frame and did not report details of the previous pain-free period. Therefore, these studies could reflect a mixture of first time, recurrent, and ongoing back pain episodes.

The included studies included temporal precursor variables such as sex, age, pubertal status, family history, socioeconomic status, and height. Potential bidirectional variables included BMI, muscle endurance and flexibility, posture, physical activity and work, screen time, inadequate sleep, carrying bags, smoking, illnesses, and psychosocial factors. Charts of the summary of findings are reported in Additional file 2.

There were 53 cross-sectional studies included in this review [38-90]. These studies reported factors that could potentially be associated with back pain such as sex, age, pubertal status, family history, and socioeconomic status. Charts of the summary of findings are seen in Additional file 3.

\section{Temporal precursor variables}

\section{Sex}

In the 53 studies reporting on sex and back pain, 32 studies found a positive association with female sex and back pain, three studies found a higher prevalence of back pain in males, and 18 studies found no association with sex (Table 1). There was generally a positive association between female sex and back pain.

\section{Age}

In the 34 studies reporting on age and back pain (Table 1), there was generally a higher prevalence of back pain with advancing age in children towards adolescence and young adulthood.

\section{Family history}

In the 19 studies reporting on family history and back pain (Table 1), there was by and large a higher prevalence in those with a positive family history of back pain.

\section{Socioeconomic status}

In 15 studies there were inconsistent estimates of association for the relationship between socioeconomic factors and back pain. Seven studies reported positive associations between certain socioeconomic factors and back pain, whereas eight studies reported no association (Table 1).

\section{Increased height or increased growth spurt}

In the 12 studies on height or increased growth there were inconsistent estimates of association for the relationship between these and back pain (Table 1). Overall height does not appear to be a risk factor for back pain.
However, the occurrence of 'growth spurts' has been found to be positively associated with back pain.

\section{Pubertal status}

As demonstrated in Table 1, in the six studies that reported on pubertal status and back pain, there was an association with back pain typically seen in those with an advanced pubertal status.

\section{History of back pain}

Three studies reported on history of back pain and risk of further back pain (Table 1). All studies found a positive association with odds ratios $\geq 2.7$.

\section{Bidirectional variables \\ Physical activity and work}

Ten studies considered physical activity and/or work as a potential risk factor of back pain. Six studies reported that with certain types of physical activity or work there was an increased prevalence of back pain, whereas four studies found no association (Table 2). It appears certain types of work such as white-collar work or manual work, and vigorous or high levels of physical activity may be associated with back pain.

\section{Psychosocial factors}

In the seven studies that tested psychosocial factors as risk factors of back pain, four studies found an increased risk of back pain, while three studies found no association (Table 2). Some psychosocial factors (depression, anxiety and 'peer problems') were associated with back pain while internalising, anxiety sensitivity, dysfunctional coping, and catastrophizing were not associated with future back pain.

\section{Body mass index}

In the eight studies that reported on BMI and back pain (Table 2), three studies reported an increased prevalence and five studies found no association (Table 2). There were inconsistent estimates of association, with insufficient evidence to conclude that there is a relationship between BMI and back pain.

\section{Smoking}

In the six studies that reported on smoking and back pain (Table 2), all found a positive association between the two. It does appear that smoking has some relationship with back pain.

\section{Systemic factors /illnesses}

Four studies tested systemic factors or illnesses as potential risk factors of back pain. Three studies found positive associations whereas one found none (Table 2). Associations with back pain were stronger with certain 
Table 1 Summary of temporal precursor variables: cross-sectional and prospective studies

\begin{tabular}{|c|c|c|c|c|c|c|}
\hline Variable & $\begin{array}{l}\text { Number of } \\
\text { studies }\end{array}$ & $\begin{array}{l}\text { Number of studies: } \\
\text { Increased risk }\end{array}$ & $\begin{array}{l}\text { Number of studies: } \\
\text { Decreased risk }\end{array}$ & $\begin{array}{l}\text { Number of studies } \\
\text { not significant }\end{array}$ & $\begin{array}{l}\text { Strength of association } \\
(95 \% \mathrm{Cl})\end{array}$ & \\
\hline Female sex & 53 & 32 & 3 & 18 & 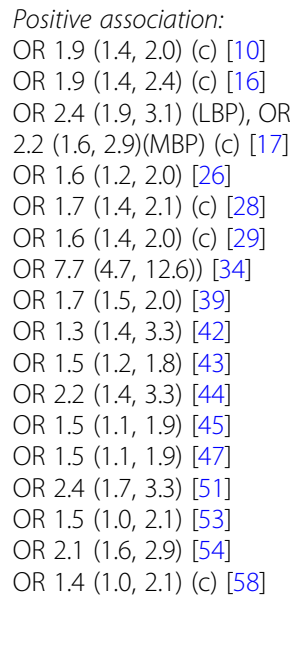 & $\begin{array}{l}\text { OR } 1.1(1.1,1.2)[59] \\
\text { OR } 1.9(1.7,2.2)[64] \\
\text { OR } 2.1(1.6,2.7)[66] \\
\text { PR } 1.1(1.1,1.2)[69] \\
\text { PR } 1.2(1.1,1.3)[70] \\
\text { OR } 1.6(1.3,2.1)[74] \\
\text { OR } 1.8(1.2,2.7) \text { (c) [76] } \\
\text { OR } 4.6(1.8,11.7)[78] \\
\text { OR } 2.2(1.6,2.9)[77] \\
\text { OR 2.4 }(1.9,3.2)[79] \\
\text { OR } 1.6(1.3,2.0) \text { (c) [81] } \\
\text { OR } 1.8(1.3,2.4) \text { (c) [83] } \\
\text { OR 2.7 (1.2,6.1) [84] } \\
\text { Females: 28\%, Males } \\
\text { 19\% }[85] \\
\text { OR 1.9 (1.3, 3.0) [89] } \\
\text { Negative association: } \\
\text { Males: HR 3.2 (2.7, 3.7) } \\
\text { [27] } \\
\text { OR 0.6 }(0.4,0.8)[50] \\
\text { OR 0.3 (0.2, 0.5) (c) [68] }\end{array}$ \\
\hline
\end{tabular}

Older Age

34

19

2

13

Positive family history

19

15

7
4

8
Positive association: OR $2.9(2.6,3.3)$ (c) [32]

OR $1.5(1.1,2.3)[35]$

OR (17 index), 21 yr 2.2

$(1.2,4.2), 23$ yr $3.2(1.7,6.2)$,

$24 \mathrm{yr} 2.8(1.5,5.3)[42]$

OR (10-11 index), 12-14 yr:

$1.1(1.1,1.3)[47]$

OR $1.1(1.1,1.2)$ [51]

(15 index) $16 / 17$ yr OR 1.7

$(1.2,2.3), 18 / 19$ yr: OR 1.8

$(1.2,2.8)[53]$

14 to $15 \mathrm{yr}$ : $6.4 \%$ increase [54]

OR 1.2 [58]

$r 0.2$ [61]

(17/18 index), $21+y r: O R$

$1.6(1.2,2.1)[65]$

(10-12 index), 13-16 yr: OR

$1.5(1.2,2.0)[66]$

(per year): OR 1.2 $(1.1,1.4)[72]$

OR $1.2(1.1,1.3)[74]$

Older $25.1 \%$, younger

adolescents $12.4 \%$ [75]

(12 index), 14 yrs.: OR 1.3

$(1.1,1.7)[80]$

Younger age: OR 1.5 (males),

OR 1.4 (females) [81]

$11 \mathrm{yr} 18 \%, 14 \mathrm{yr} 34 \%$ (girls)

11 yr $14 \%, 14$ yr $25 \%$ (boys) [85]

OR $1.3(1.1,1.7)$ [88]

OR $1.3(1.2-1.4)$ [89]

Negative association:

Younger age: OR 0.2

$(0.1,0.6)[46]$

OR $0.5(0.4,0.6)[67]$

$\begin{array}{ll}\text { OR 3.6 }(1.3,10.2)[11] & \text { OR } 1.7[58] \\ \text { OR 2.1 }(1.4,3.1)[35] & \text { OR } 1.8(1.5,2.0)[64] \\ \text { OR 2.0 }(1.1,4.0)[36] & \text { PR } 1.2(1.2,1.3)[69] \\ \text { OR 2.6 }(1.4,5.9)[38] & \text { PR } 1.2(1.1,1.3)[70] \\ \text { OR 2.1 }[40] & \text { OR } 2.0(1.2,3.3)[72] \\ \text { OR 3.8 }(2.9,5.9)[41] & \text { OR 2.3 }(1.2,4.7)[89] \\ \text { OR 1.8 }(1.4,2.4)[43] & \text { OR } 2.6(1.9,3.6)[90] \\ \text { OR: } 1.5(1.1,1.9)(c)[48] & \end{array}$

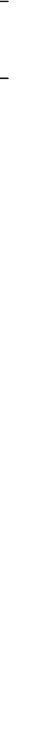


Table 1 Summary of temporal precursor variables: cross-sectional and prospective studies (Continued)

\begin{tabular}{|c|c|c|c|c|c|}
\hline Variable & $\begin{array}{l}\text { Number of } \\
\text { studies }\end{array}$ & $\begin{array}{l}\text { Number of studies: } \\
\text { Increased risk }\end{array}$ & $\begin{array}{l}\text { Number of studies: } \\
\text { Decreased risk }\end{array}$ & $\begin{array}{l}\text { Number of studies } \\
\text { not significant }\end{array}$ & $\begin{array}{l}\text { Strength of association } \\
(95 \% \mathrm{Cl})\end{array}$ \\
\hline & & & & & $\begin{array}{l}\text { OR } 0.8(0.7,1.0)[34] \\
\text { Higher social class: OR: } 0.9 \\
(0.8,0.9)[55] \\
\text { Parental low level of education: } \\
\text { OR 1.8 (1.1, 2.0) [62] } \\
\text { Ethnicity: (Index white) } \\
\text { Asian PR: } 1.2(1.1,1.4), \\
\text { indigenous PR: } 1.4(1.3,1.5)[70] \\
\text { Non-white: PR } 1.4(1.0,1.9)[71] \\
\text { Location (index peripheral center) } \\
\text { Urban centre: OR } 3.1[73] \\
\text { Residence: } 52 \% \text { (city), 43\% } \\
\text { (village) [83] }\end{array}$ \\
\hline $\begin{array}{l}\text { Increased height or } \\
\text { increased growth spurt }\end{array}$ & 12 & 4 & 1 & 7 & $\begin{array}{l}\text { High growth spurt: OR } 3.1 \\
(1.5,6.0)[4] \\
\text { linear growth: IRR } 1.2 \\
(1.2,1.2)[18] \\
\text { Shorter than median height } \\
(158 \mathrm{~cm}) \text { : RR } 2.1(1.2,3.8)[23] \\
\text { Height: OR } 1.2(1.0-1.5)[31] \\
\text { Taller: } t \text { test }-3.3[58]\end{array}$ \\
\hline Later pubertal status & 6 & 4 & 1 & 1 & $\begin{array}{l}\text { Positive association } \\
\text { IRR } 1.5(1.2,2.0) \text { (Tanner stage 2), } \\
\text { IRR } 2.1(1.5,3.0) \text { (Tanner stage 3) } \\
\text { IRR } 3.3(2.1,5.0) \text { (Tanner stage 4/5) [18] } \\
\text { OR 1.6 }(1.3,2.0) \text { (USA), OR 1.3 } \\
\text { (1.1, 1.6) (Dutch) [22] } \\
\text { OR 2.0 (girls), OR 1.9 (boys) [63] } \\
\text { Stage 4: OR 2.0 (1.3, 3.5), stage 5: } \\
\text { OR 2.1 (1.1, 1.4) [86] } \\
\text { Negative association: } \\
\text { HR 0.6 }(0.5,0.8) \text { (males) [27] }\end{array}$ \\
\hline History of back pain & 3 & 3 & 0 & 0 & $\begin{array}{l}\text { BP in adolescence for BP in } \\
\text { adulthood: OR 4.3 }(3.5,5.4)[21] \\
\text { History of BP: OR 2.7 }(1.1,7.1) \\
\text { (ever), OR 9.1 (3.0, 27.2) (> } 7 \text { days) [33] } \\
\text { History of BP: OR } 7.7(4.7-12.6) \\
\text { (girls) [34] }\end{array}$ \\
\hline
\end{tabular}

$O R$ odds ratio, $P R$ prevalence ratio, $H R$ hazard ratio, $R R$ relative risk, $I R R$ incidence rate ratio, $L B P$ low back pain, $M B P$ mid back pain, $B P$ back pain, (c): parameter measure calculated from the provided results within study i.e. percentages converted to odds ratios

systemic diseases such as having asthma, headaches, abdominal pain, and colds/minor illnesses. These may be co-morbidities to back pain, meaning that one could be a precursor to the other or they could have a common cause.

\section{Spinal posture and sitting posture}

Four studies reported on certain aspects of posture and back pain (Table 2). All four studies indicated that from a preliminary viewpoint abnormal spinal posture and certain sitting positions were associated with back pain.

\section{Sleep}

As seen in Table 2, in the three studies that reported on sleep and back pain, there was a positive association between back pain and insufficient sleep.

\section{Flexibility}

Three studies tested muscle flexibility as a risk factor for back pain (Table 2). Two studies found a positive association with decreased flexibility of hamstrings or quadriceps, and back pain, while one study found no association.

\section{Screen time}

Three studies reported inconsistent estimates of associations between screen time and back pain. One study reported a higher prevalence of back pain with increased television time, whereas two reported none (Table 2).

\section{Backpack factors}

In three studies, there were inconsistent estimates of association between backpack factors and back pain. One study of these three reported a higher prevalence of back pain with a heavier school satchel (Table 2). 
Table 2 Summary of bidirectional variables

\begin{tabular}{|c|c|c|c|c|c|}
\hline Variable & $\begin{array}{l}\text { Number } \\
\text { of studies }\end{array}$ & $\begin{array}{l}\text { Number of } \\
\text { studies: Increased } \\
\text { risk }\end{array}$ & $\begin{array}{l}\text { Number of studies: } \\
\text { Decreased risk }\end{array}$ & $\begin{array}{l}\text { Number of studies } \\
\text { not significant }\end{array}$ & Strength of association $(95 \% \mathrm{Cl})$ \\
\hline $\begin{array}{l}\text { Physical } \\
\text { activity/work }\end{array}$ & 10 & 6 & 0 & 4 & $\begin{array}{l}\text { Playing sport OR } 9.5(1.9,48.2)[11] \\
\text { White collar work OR 4.9 }(1.7,14.2)[13] \\
\text { Vigorous intensity physical activity: OR } 1.2(1.0-1.4) \\
\text { (diagnostic spinal pain) OR } 1.3(1.0-1.5) \text { (traumatic) [15] } \\
\text { High level sports activity RR } 1.6(1.1,2.3)[24] \text {, Part-time } \\
\text { work RR } 1.5(1.1,2.1)[24] \\
\text { Provoked by manual work: OR } 9.2(2.9,28.8)[33] \\
\text { Increased physical activity OR } 1.9(1.2,2.8)[34]\end{array}$ \\
\hline $\begin{array}{l}\text { Psychological } \\
\text { factors }\end{array}$ & 7 & 4 & 0 & 3 & $\begin{array}{l}\text { High level of peer problems: RR } 2.3(1.3,4.2)[23] \\
\text { High level of psychological factors: RR 1.6 }(1.1,2.3)[24] \\
\text { Externalising behaviour: RR 1.5 }(1.3,1.7)(\text { boys), RR } 1.4 \\
(1.3,1.5) \text { (girls), RR } 3.6(1.5,8.5) \text { (girls 18) [28] } \\
\text { High levels of aggressive behaviour OR 1.4 }(1.2,1.6)[34] \\
\text { High level of somatic complaints OR 1.3 }(1.1,1.5)[34]\end{array}$ \\
\hline Higher BMI & 8 & 3 & 0 & 5 & $\begin{array}{l}\text { OR } 1.3(1.0,1.5)[11] \\
\text { RR } 1.1(1.0,1.2) \text { (girls), RR } 1.1(1.0,1.3) \text { (boys) }[29] \\
\text { OR } 2.9(1.7,5.1)(9 \mathrm{yr}), 2.2(1.4,3.5)(10 \mathrm{yr}), 1.6(1.2,2.1) \\
(13 \mathrm{yr})[32]\end{array}$ \\
\hline Smoking & 6 & 6 & 0 & 0 & $\begin{array}{l}\text { OR } 2.2(1.4,3.5)[4] \\
\text { OR } 2.4(1.3,6.0)[14] \\
\text { OR } 3.1(1.1,9.2)(\mathrm{MB}), 1.8(1.2,2.8)(\mathrm{BP})[17] \\
\text { OR } 1.7(1.4,2.1)[19] \\
\text { HR } 1.6(1.4,1.9)[27] \\
\text { OR } 2.5(1.4,4.5) \text { (females) }[30]\end{array}$ \\
\hline Illness & 4 & 3 & 0 & 1 & $\begin{array}{l}\text { Asthma OR } 1.4(1.1,1.7) \text { (female) [20] } \\
\text { Headache OR } 1.6(1.1,2.1) \text { (female), OR } 2.4(1.2,4.7) \\
\text { (male) }[20] \\
\text { Abdominal pain RR } 1.8(1.1,3.0)[24] \\
\text { Headache OR } 2.4(1.8,3.1)[26]\end{array}$ \\
\hline $\begin{array}{l}\text { Posture/ } \\
\text { sitting } \\
\text { position }\end{array}$ & 4 & 4 & 0 & 0 & $\begin{array}{l}\text { No LB support: OR } 1.7(1.2,2.6), \text { OR } 2.9(1.1,3.5) \\
\text { (persistent LBP) }[25] \\
\text { Provoked by sitting OR } 3.8(1.3,11.3)[33] \\
\text { Non-neutral standing posture OR } 2.2(1.3,3.6)[34] \\
\text { Uncomfortable school desk OR } 6.0(3.7,9.7)[35]\end{array}$ \\
\hline $\begin{array}{l}\text { Insufficient } \\
\text { sleep }\end{array}$ & 3 & 3 & 0 & 0 & $\begin{array}{l}\text { OR } 2.9(1.7,5.2) \text { (girls), OR } 2.4(1.3,4.5) \text { (boys) }[10] \\
\text { OR } 2.2(1.7,3.8)[35] \\
\text { OR } 1.2(1.1,1.4)[36]\end{array}$ \\
\hline Flexibility & 3 & 2 & 0 & 1 & $\begin{array}{l}\text { Decreased flexibility: hamstrings OR } 1.1(1.0,1.1)[4] \\
\text { Decreased flexibility: quad muscles: OR } 1.7(1.1,2.8)[25]\end{array}$ \\
\hline Screen time & 3 & 1 & 0 & 2 & Increased TV time OR $2.0(1.4,2.9)[35]$ \\
\hline $\begin{array}{l}\text { Backpack } \\
\text { factors }\end{array}$ & 3 & 1 & 0 & 2 & Heavy school satchel OR $2.2(1.0,4.8)[36]$ \\
\hline $\begin{array}{l}\text { Muscle } \\
\text { endurance }\end{array}$ & 1 & 1 & 0 & 0 & Poor back muscle endurance OR $1.9(1.2,3.0)[34]$ \\
\hline
\end{tabular}

$O R$ odds ratio, $R R$ relative risk, $H R$ hazard ratio, (c) parameter measure calculated from the provided results within study i.e. percentages converted to odds ratios

\section{Muscle endurance}

In the one study that tested muscle endurance as a risk factor of back pain, it was found that those with poor back muscle endurance had a positive association with back pain (Table 2).

\section{Discussion}

Overall summary of potential risk factors from all studies Considering the existing literature, the factors found to be likely risk factors or triggers for back pain are female sex, older age, advanced pubertal status, high growth rate, positive family history of back pain, a history of back pain, smoking, and insufficient sleep. Most of these factors are temporal precursor. Further, they are mostly biological and non-modifiable, making them ineligible targets for preventative interventions. No association or weak associations were noted with increased screen time and work. There were mixed results for muscle flexibility, socioeconomic status, backpack-related factors, anthropometric measures including height and weight, and physical activity. There was limited research for systemic/illness 
factors, muscle endurance, spinal posture, and sitting position (Table 3).

\section{Implications of results}

Previous systematic reviews found the most likely risk factors for back pain in young people to be female sex [9193], older age [91, 92, 94], advanced pubertal status [95], positive family history of back pain [96], and a previous history of back pain $[93,97]$. We advanced this knowledge by further considering the temporal relationship between the risk factors and back pain and we concluded that the most likely risk factors or triggers for back pain are predominantly biological. For example, the genetic component of back pain is potentially large [98]. A systematic review found that estimates of heritability effects ranged from 21 to 67\% [99]. However, environmental exposures also have an effect, so the question arises; how large is this effect? This question could be addressed through further twin control studies. Twin studies have an advantage of reducing confounding due to genetics and can be utilised to explore the potential causal pathway between environmental factors, co-morbidities and back pain [99].

Considering the strength of associations, some factors were statistically linked to back pain, but the next question arises, are they important on a clinical or individual level?
Another issue to consider is that individual associations may well be relatively weak, but it is possible that combination of factors or the addition of factors could increase the risk of back pain rather than individual factors. This idea has been proposed previously through a dynamic multifactorial and recursive model of aetiology [100]. This model emphasizes the importance of investigating intrinsic predisposing factors along with the extrinsic factors that interact together to make an individual vulnerable to injury [100]. Certain predictive risk factors could predispose individuals to back pain, and then in combination with other potentially causal risk factors, the individual could develop back pain. For example, girls (factor 1) with advanced pubertal status (factor 2) could be susceptible to back pain that is subsequently caused by vigorous physical activity (factor 3 ). Therefore, from a clinical perspective, it might be important to consider the person as a whole.

\section{Limitations of the current literature}

The foremost limitations of the current literature are that the majority of studies are cross-sectional, or if longitudinal, most do not start data collection before the onset of back pain. To investigate temporality, one criterion to establish causal relationships, risk factors should be captured before the inception of the disease [101]. Therefore, the conclusions of this scoping review

Table 3 Summary of Potential Risk factors

\begin{tabular}{|c|c|c|c|c|}
\hline Potential risk factor & Likely & Weak/no significance & Mixed results/ inconsistent & Limited research \\
\hline Female sex & $x$ & & & \\
\hline Older age/ advanced pubertal status & $x$ & & & \\
\hline Positive family history of back pain & $x$ & & & \\
\hline Increased growth spurt & $x$ & & & \\
\hline History of back pain & $x$ & & & \\
\hline Smoking & $x$ & & & \\
\hline Insufficient sleep & $x$ & & & \\
\hline Increased screen time & & $x$ & & \\
\hline Work & & $x$ & & \\
\hline Psychosocial factors & & & $x$ & \\
\hline Muscle flexibility & & & $x$ & \\
\hline Socioeconomic status & & & $x$ & \\
\hline Backpack related factors & & & $x$ & \\
\hline Height and weight & & & $x$ & \\
\hline Physical activity & & & $x$ & \\
\hline Spinal posture & & & & $x$ \\
\hline Sitting position & & & & $x$ \\
\hline Systemic/illness factors & & & & $x$ \\
\hline Muscle endurance & & & & $x$ \\
\hline
\end{tabular}


are limited to demonstrating association and not causation. Additionally, the definitions of 'back pain' vary from study to study (Additional files 4 and 5), this means it is not clear whether authors are considering back pain as a disease or an episode [101], or whether they are asking about back pain currently, for the past week, for the past month, or for the past year. Although the purpose of this review was to include risk factors or triggers for pain the thoracic and/or lumbar spine, some of the included studies included spinal pain in general $[9,15,16,18,35,39,86-89]$. While other studies included back pain without a clear definition of location $[22,26,49,50,56,61,63,69,70,74,81]$, and therefore it is unclear what they were looking at. As the definitions on back pain are not always clear or inconsistent it is difficult to make clear definitive statements.

\section{Limitations of this review}

A potential limitation of the validity of data collected in this scoping review is that only one researcher screened and conducted data charting. Nevertheless, articles were screened twice, by the same reviewer, and a second researcher verified the process, which is consistent with the PRISMA-ScR guidelines. Only two key databases were searched, and articles were limited to English language. Consequently, we may have missed some articles. Nevertheless, this type of literature is quite stereotyped, for which reason it is unlikely that any missing articles would be of significance.

There were some contradictory findings in our result tables. Contradictory findings often result from differences in study populations, definitions of the outcome or independent variables, and differences in data quality. However, due to the nature of scoping reviews, which lack the critical approach of systematic reviews, such contradictions cannot be interpreted. Due to the nature of conflicting data the summary of potential risk factors is indicative but not unequivocal.

\section{Recommendations for future research}

Future studies should collect data from the inception of back pain by following the population from earlier life, if searching for causes of the 'disease' back pain. They should additionally collect data on proposed risk factors before the onset of back pain. If studies are attempting to identify triggers of future events, back pain episodes must be separated by nonepisodes.

As highlighted within this scoping review (Additional files 4 and 5), future research should ensure that data are collected with a clear definition of back pain and ideally measured through a validated questionnaire. Additionally, future research should be more innovative in the way that risk factors are considered. This could be through statistical approaches including cumulative exposures, or longitudinal approaches such as multi-trajectory methods and through the use of twin studies.

\section{Conclusion}

Many of the included studies approached identifying risk factors in similar ways and found factors that were associated with back pain but were not obvious risk factors as causality was uncertain. Obviously, the time has come to approach this problem in other ways. It is our opinion that future research should be more rigorous and innovative in the way that risk factors for back pain are considered.

\section{Supplementary information}

Supplementary information accompanies this paper at https://doi.org/10. 1186/s12998-019-0281-8.

Additional file 1. Search strategies used for the literature search. The full search strategy for PubMed and Cochrane databases.

Additional file 2. PROSPECTIVE STUDIES reporting factors that are longitudinally associated with back pain. Table summarising each included prospective study.

Additional file 3. CROSS-SECTIONAL STUDIES reporting factors that are associated with back pain. Table summarising included cross-sectional study.

Additional file 4. Clarity of definitions of Back pain: Prospective studies. Table summarising the clarity of the definitions of back pain in included prospective studies.

Additional file 5. Clarity of definitions of Back pain: Cross-sectional stud ies. Table summarising the clarity of the definitions of back pain in included cross-sectional studies.

\section{Abbreviations}

BMI: Body mass index; BP: Back pain; Cl: Confidence intervals; HR: Hazard ratio; IRR: Incidence rate ratio; LBP: Low back pain; MBP: Mid back pain; N: Number of participants; NA: Not applicable; OR: Odds ratio; PR: Prevalence ratio; RR: Relative risk

\section{Acknowledgements}

This research was carried out with funding provided by Chiropractic Australia Research Foundation.

\section{Authors' contributions}

All authors contributed to the design of the study. $A B$ conducted the search, study selection and data charting. $A B$ analysed and interpreted the data with the assistance of BW, JH and CLY. AB drafted the manuscript and performed revisions with substantial feedback and editing from all authors. All authors read and approved the final manuscript.

\section{Funding}

This study was funded by a scholarship from Murdoch University, Western Australia and funding provided by Chiropractic Australia Research Foundation. JH receives salary support from the Canadian Chiropractic Research Foundation and the New Brunswick Health Research Foundation. The funding sources had no involvement in study design, analysis, interpretation, or manuscript preparation. 


\section{Availability of data and materials}

Not applicable.

\section{Ethics approval and consent to participate}

Not applicable.

\section{Consent for publication}

Not applicable.

\section{Competing interests}

BW and JH are both editors and CLY is Senior Editorial Advisor of Chiropractic \& Manual Therapies but played no part in the review of this submission and were blinded to the process. $\mathrm{JH}$ is an executive member of the Chiropractic Australia Research Foundation.

\section{Author details}

'College of Science, Health, Engineering and Education, Murdoch University, 90 South Street, Murdoch 6150, Western Australia, Australia. ${ }^{2}$ Faculty of Kinesiology, University of New Brunswick, 3 Bailey Drive, Fredericton, New Brunswick E3B 5A3, Canada. Institute for Regional Health Research, University of Southern Denmark, Odense, Denmark.

Received: 10 April 2019 Accepted: 9 September 2019

Published online: 19 November 2019

\section{References}

1. Hoy D, Bain C, Williams G, March L, Brooks P, Blyth F, et al. A systematic review of the global prevalence of low back pain. Arthritis Rheum. 2012; 64(6):2028-37.

2. Balague F, Troussier B, Salminen JJ. Non-specific low back pain in children and adolescents: risk factors. Eur Spine J. 1999;8(6):429-38.

3. Kjaer P, Wedderkopp N, Korsholm L, Leboeuf-Yde C. Prevalence and tracking of back pain from childhood to adolescence. BMC Musculoskelet Disord. 2011:12(1):98

4. Feldman DE, Shrier I, Rossignol M, Abenhaim L. Risk factors for the development of low back pain in adolescence. Am J Epidemiol. 2001; 154(1):30-6

5. Tricco AC, Lillie E, Zarin W, O'Brien KK, Colquhoun H, Levac D, et al. PRISMA extension for scoping reviews (PRISMA-SCR): checklist and explanation. Ann Intern Med. 2018;169(7):467-73.

6. Sawyer SM, Azzopardi PS, Wickremarathne D, Patton GC. The age of adolescence. Lancet Child Adolesc Health. 2018;2(3):223-8.

7. Hill $A B$. The environment and disease: association or causation? London: SAGE Publications; 1965

8. Peters MD, Godfrey CM, Khalil H, Mclnerney P, Parker D, Soares CB. Guidance for conducting systematic scoping reviews. Int J Evid Based Healthc. 2015:13(3):141-6.

9. Aartun E, Hartvigsen J, Boyle E, Hestbaek L. No associations between objectively measured physical activity and spinal pain in 11-15-year-old Danes. Eur J Pain. 2016;20(3):447-57.

10. Auvinen JP, Tammelin TH, Taimela SP, Zitting PJ, Jarvelin MR, Taanila AM, et al. Is insufficient quantity and quality of sleep a risk factor for neck, shoulder and low back pain? A longitudinal study among adolescents. Eur Spine J. 2010:19(4):641-9.

11. Balagué F, Bibbo E, Mélot C, Szpalski M, Gunzburg R, Keller TS. The association between isoinertial trunk muscle performance and low back pain in male adolescents. Eur Spine J. 2010;19(4):624-32.

12. Deere KC, Clinch J, Holliday K, McBeth J, Crawley EM, Sayers A, et al. Obesity is a risk factor for musculoskeletal pain in adolescents: findings from a population-based cohort. Pain. 2012:153(9):1932-8.

13. Feldman DE, Shrier I, Rossignol M, Abenhaim L. Work is a risk factor for adolescent musculoskeletal pain. J Occup Environ Med. 2002:44(10):956-61.

14. Feldman DE, Rossignol M, Shrier I, Abenhaim LS. A risk factor for development of low back pain in adolescents. Spine (Phila Pa 1976). 1999;24(23):2492-6.

15. Franz C, Møller NC, Korsholm L, Jespersen E, Hebert JJ, Wedderkopp N Physical activity is prospectively associated with spinal pain in children (CHAMPS study-DK). Sci Rep. 2017;7(1):11598.

16. Franz C, Jespersen E, Rexen C, Leboeuf-Yde C, Wedderkopp N. Back injuries in a cohort of schoolchildren aged 6-12: a 2.5-year prospective study. Scand J Med Sci Sports. 2016;26(8):911-8.
17. Gill DK, Davis MC, Smith AJ, Straker LM. Bidirectional relationships between cigarette use and spinal pain in adolescents accounting for psychosocial functioning. Br J Health Psychol. 2014;19(1):113-31.

18. Hebert JJ, Leboeuf-Yde C, Franz C, Lardon A, Hestbæk L, Manson N, et al. Pubertal development and growth are prospectively associated with spinal pain in young people (CHAMPS study-DK). Eur Spine J. 2019;28:1565-71.

19. Hestbaek L, Leboeuf-Yde C, Kyvik KO. Are lifestyle-factors in adolescence predictors for adult low back pain? A cross-sectional and prospective study of young twins. BMC Musculoskelet Disord. 2006;7:27.

20. Hestbaek L, Leboeuf-Yde C, Kyvik KO. Is comorbidity in adolescence a predictor for adult low back pain? A prospective study of a young population. BMC Musculoskelet Disord. 2006;7(1):29.

21. Hestbaek L, Leboeuf-Yde C, Kyvik KO, Manniche C. The course of low back pain from adolescence to adulthood: eight-year follow-up of 9600 twins. Spine (Phila Pa 1976). 2006:31(4):468-72.

22. Janssens KA, Rosmalen JG, Ormel J, Verhulst FC, Hunfeld JA, Mand LA, et al. Pubertal status predicts back pain, overtiredness, and dizziness in American and Dutch adolescents. Pediatrics. 2011;128(3):553-9.

23. Jones GT, Macfarlane GJ. Predicting persistent low back pain in schoolchildren: a prospective cohort study. Arthritis Rheum. 2009;61(10):1359-66.

24. Jones GT, Watson KD, Silman AJ, Symmons DP, Macfarlane GJ. Predictors of low back pain in British schoolchildren: a population-based prospective cohort study. Pediatrics. 2003;111(4 Pt 1):822-8.

25. Kanchanomai S, Janwantanakul P, Pensri P, Jiamjarasrangsi W. A prospective study of incidence and risk factors for the onset and persistence of low back pain in Thai university students. Asia Pac J Public Health. 2015;27(2):Np106-15.

26. Kroner-Herwig B, Gorbunova A, Maas J. Predicting the occurrence of headache and back pain in young adults by biopsychological characteristics assessed at childhood or adolescence. Adolesc Health Med Ther. 2017:8:31-9.

27. Mattila VM, Saarni L, Parkkari J, Koivusilta L, Rimpelä A. Predictors of low back pain hospitalization-a prospective follow-up of 57,408 adolescents. Pain. 2008;139(1):209-17.

28. Mikkonen P, Heikkala E, Paananen M, Remes J, Taimela S, Auvinen J, et al. Accumulation of psychosocial and lifestyle factors and risk of low back pain in adolescence: a cohort study. Eur Spine J. 2016;25(2):635-42.

29. Mikkonen PH, Laitinen J, Remes J, Tammelin T, Taimela S, Kaikkonen K, et al. Association between overweight and low back pain: a population-based prospective cohort study of adolescents. Spine (Phila Pa 1976). 2013;38(12):1026-33.

30. Mikkonen $P$, Leino-Arjas $P$, Remes J, Zitting P, Taimela S, Karppinen J. Is smoking a risk factor for low back pain in adolescents? A prospective cohort study. Spine (Phila Pa 1976). 2008;33(5):527-32.

31. Nissinen $M$, Heliovaara M, Seitsamo J, Alaranta H, Poussa M. Anthropometric measurements and the incidence of low back pain in a cohort of pubertal children. Spine (Phila Pa 1976). 1994;19(12):1367-70.

32. Sano A, Hirano T, Watanabe $K$, Endo N, Ito T, Tanabe N. Body mass index is associated with low back pain in childhood and adolescence: a birth cohort study with a 6-year follow-up in Niigata City, Japan. Eur Spine J. 2015;24(3):474-81.

33. Sjolie AN. Persistence and change in nonspecific low back pain among adolescents: a 3-year prospective study. Spine (Phila Pa 1976). 2004;29(21):2452-7.

34. Smith A, Beales D, O'Sullivan P, Bear N, Straker L. Low Back pain with impact at 17 years of age is predicted by Early adolescent risk factors from multiple domains: analysis of the Western Australian pregnancy cohort (Raine) study. J Orthop Sports Phys Ther. 2017:47(10):752-62.

35. Szita J, Boja S, Szilagyi A, Somhegyi A, Varga PP, Lazary A. Risk factors of non-specific spinal pain in childhood. Eur Spine J. 2018;27(5):1119-26.

36. Szpalski M, Gunzburg R, Balague F, Nordin M, Melot C. A 2-year prospective longitudinal study on low back pain in primary school children. Eur Spine J. 2002;11(5):459-64

37. Tobias JH, Deere K, Palmer S, Clark EM, Clinch J. Joint hypermobility is a risk factor for musculoskeletal pain during adolescence: findings of a prospective cohort study. Arthritis Rheum. 2013;65(4):1107-15.

38. Aggarwal N, Anand T, Kishore J, Ingle GK. Low back pain and associated risk factors among undergraduate students of a medical college in Delhi. Educ Health (Abingdon). 2013;26(2):103-8.

39. Andersen L, Wedderkopp N, Leboeuf-Yde C. Association between back pain and physical fitness in adolescents. Spine (Phila Pa 1976). 2006; 31(15):1740-4.

40. Balague F, Nordin M, Skovron ML, Dutoit G, Yee A, Waldburger M. Nonspecific low-back pain among schoolchildren: a field survey with analysis of some associated factors. J Spinal Disord. 1994;7(5):374-9. 
41. Bejia I, Abid N, Ben Salem K, Letaief M, Younes M, Touzi M, et al. Low back pain in a cohort of 622 Tunisian schoolchildren and adolescents: an epidemiological study. Eur Spine J. 2005;14(4):331-6.

42. Cakmak A, Yucel B, Ozyalen SN, Bayraktar B, Ural HI, Duruoz MT, et al. The frequency and associated factors of low back pain among a younger population in Turkey. Spine (Phila Pa 1976). 2004;29(14):1567-72.

43. Dianat I, Alipour A, Asghari Jafarabadi M. Prevalence and risk factors of low back pain among school age children in Iran. Health Promot Perspect. 2017;7(4):223-9.

44. Dianat I, Sorkhi N, Pourhossein A, Alipour A, Asghari-Jafarabadi M. Neck, shoulder and low back pain in secondary schoolchildren in relation to schoolbag carriage: should the recommended weight limits be genderspecific? Appl Ergon. 2014;45(3):437-42.

45. Diepenmaat AC, van der Wal MF, de Vet HC, Hirasing RA. Neck/ shoulder, low back, and arm pain in relation to computer use, physical activity, stress, and depression among Dutch adolescents. Pediatrics. 2006;117(2):412-6.

46. Erne C, Elfering A. Low back pain at school: unique risk deriving from unsatisfactory grade in maths and school-type recommendation. Eur Spine J. 2011;20(12):2126-33

47. Fernandes JA, Genebra CV, Maciel NM, Fiorelli A, de Conti MH, De Vitta A Low back pain in schoolchildren: a cross-sectional study in a western city of Sao Paulo state, Brazil. Acta Ortop Bras. 2015;23(5):235-8.

48. Ganesan S, Acharya AS, Chauhan R, Acharya S. Prevalence and risk factors for low Back pain in 1,355 young adults: a cross-sectional study. Asian Spine J. 2017;11(4):610-7.

49. Ghandour RM, Overpeck MD, Huang ZJ, Kogan MD, Scheidt PC. Headache, stomachache, backache, and morning fatigue among adolescent girls in the United States: associations with behavioral, sociodemographic, and environmental factors. Arch Pediatr Adolesc Med. 2004;158(8):797-803

50. Gilkey DP, Keefe TJ, Peel JL, Kassab OM, Kennedy CA. Risk factors associated with back pain: a cross-sectional study of 963 college students. J Manip Physiol Ther. 2010;33(2):88-95.

51. Graup S, de Araujo Bergmann ML, Bergmann GG. Prevalence of nonspecific lumbar pain and associated factors among adolescents in Uruguaiana, state of Rio Grande do Sul. Rev Bras Ortop. 2014;49(6):661-7.

52. Gunzburg R, Balague F, Nordin M, Szpalski M, Duyck D, Bull D, et al. Low back pain in a population of school children. Eur Spine J. 1999;8(6):439-43.

53. Haag TB, Mayer HM, Schneider AS, Rumpf MC, Handel M, Schneider C Risk assessment of back pain in youth soccer players. Res Sports Med. 2016;24(4):395-406.

54. Harreby M, Nygaard B, Jessen T, Larsen E, Storr-Paulsen A, Lindahl A, et al. Risk factors for low back pain in a cohort of 1389 Danish school children: an epidemiologic study. Eur Spine J. 1999;8(6):444-50.

55. Hestbaek L, Korsholm L, Leboeuf-Yde C, Kyvik KO. Does socioeconomic status in adolescence predict low back pain in adulthood? A repeated cross-sectional study of 4,771 Danish adolescents. Eur Spine J. 2008;17(12):1727-34.

56. Hulsegge G, van Oostrom SH, Picavet HS, Twisk JW, Postma DS, Kerkhof M, et al. Musculoskeletal complaints among 11-year-old children and associated factors: the PIAMA birth cohort study. Am J Epidemiol. 2011;174(8):877-84.

57. Jones GT, Silman AJ, Macfarlane GJ. Parental pain is not associated with pain in the child: a population based study. Ann Rheum Dis. 2004;63(9):1152-4.

58. Kaspiris A, Grivas TB, Zafiropoulou C, Vasiliadis E, Tsadira O. Nonspecific low back pain during childhood: a retrospective epidemiological study of risk factors. J Clin Rheumatol. 2010;16(2):55-60.

59. Kovacs FM, Gestoso M, Gil del Real MT, Lopez J, Mufraggi N, Mendez Jl. Risk factors for non-specific low back pain in schoolchildren and their parents: a population based study. Pain. 2003;103(3):259-68.

60. Kristensen C, Bø K, Ommundsen Y. Level of physical activity and low back pain in randomly selected 15-year-olds in Oslo, Norway -- an epidemiological study based on survey. Adv Physiother. 2001;3(2):86-91.

61. Kristjansdottir $\mathrm{G}$, Rhee $\mathrm{H}$. Risk factors of back pain frequency in schoolchildren: a search for explanations to a public health problem. Acta Paediatr. 2002;91(7):849-54

62. Leboeuf-Yde C, Wedderkopp N, Andersen LB, Froberg K, Hansen HS. Back pain reporting in children and adolescents: the impact of parents' educational level. J Manip Physiol Ther. 2002;25(4):216-20.

63. LeResche L, Mancl LA, Drangsholt MT, Saunders K, Von Korff M. Relationship of pain and symptoms to pubertal development in adolescents. Pain. 2005; 118(1-2):201-9.
64. Masiero S, Carraro E, Celia A, Sarto D, Ermani M. Prevalence of nonspecific low back pain in schoolchildren aged between 13 and 15 years. Acta Paediatr. 2008;97(2):212-6.

65. Mattila VM, Sahi T, Jormanainen V, Pihlajamaki H. Low back pain and its risk indicators: a survey of 7,040 Finnish male conscripts. Eur Spine J. 2008;17(1):64-9.

66. Minghelli B, Oliveira R, Nunes C. Non-specific low back pain in adolescents from the south of Portugal: prevalence and associated factors. J Orthop Sci. 2014;19(6):883-92.

67. Mohseni-Bandpei MA, Bagheri-Nesami M, Shayesteh-Azar M. Nonspecific low back pain in 5000 Iranian school-age children. J Pediatr Orthop. 2007;27(2):126-9.

68. Ng L, Perich D, Burnett A, Campbell A, O'Sullivan P. Self-reported prevalence, pain intensity and risk factors of low back pain in adolescent rowers. J Sci Med Sport. 2014;17(3):266-70.

69. Noll M, Candotti CT, Rosa BN, Loss JF. Back pain prevalence and associated factors in children and adolescents: an epidemiological population study. Rev Saude Publica. 2016;50:31.

70. Noll M, de Avelar IS, Lehnen GC, Vieira MF. Back pain prevalence and its associated factors in Brazilian athletes from public high schools: a crosssectional study. PLoS One. 2016;11(3):e0150542.

71. Onofrio AC, da Silva MC, Domingues MR, Rombaldi AJ. Acute low back pain in high school adolescents in southern Brazil: prevalence and associated factors. Eur Spine J. 2012;21(7):1234-40

72. Pasanen K, Rossi M, Parkkari J, Kannus P, Heinonen A, Tokola K, et al. Low Back pain in young basketball and floorball players. Clin J Sport Med. 2016;26(5):376-80.

73. Prista A, Balagué F, Nordin M, Skovron ML. Low back pain in Mozambican adolescents. Eur Spine J. 2004;13(4):341-5.

74. Rodriguez-Oviedo P, Ruano-Ravina A, Perez-Rios M, Garcia FB, GomezFernandez D, Fernandez-Alonso A, et al. School children's backpacks, back pain and back pathologies. Arch Dis Child. 2012;97(8):730-2.

75. Scarabottolo CC, Pinto RZ, Oliveira CB, Zanuto EF, Cardoso JR, Christofaro DGD. Back and neck pain prevalence and their association with physical inactivity domains in adolescents. Eur Spine J. 2017:26:2274-80.

76. Shehab D, Al-Jarallah K, Al-Ghareeb F, Sanaseeri S, Al-Fadhli M, Habeeb S. Is low-back pain prevalent among Kuwaiti children and adolescents? A governorate-based study. Med Princ Pract. 2004;13(3):142-6.

77. Sheir-Neiss GI, Kruse RW, Rahman T, Jacobson LP, Pelli JA. The association of backpack use and back pain in adolescents. Spine (Phila Pa 1976). 2003;28(9):922-30.

78. Shipp EM, Cooper SP, Del Junco DJ, Delclos GL, Burau KD, Tortolero SR. Severe back pain among farmworker high school students from Starr County, Texas: baseline results. Ann Epidemiol. 2007;17(2):132-41.

79. Silva GR, Pitangui AC, Xavier MK, Correia-Junior MA, De Araujo RC. Prevalence of musculoskeletal pain in adolescents and association with computer and videogame use. J Pediatr. 2016;92(2):188-96.

80. Silva MR, Badaro AF, Dall'Agnol MM. Low back pain in adolescent and associated factors: a cross sectional study with schoolchildren. Braz J Phys Ther. 2014;18(5):402-9.

81. Skaggs DL, Early SD, D'Ambra P, Tolo VT, Kay RM. Back pain and backpacks in school children. J Pediatr Orthop. 2006;26(3):358-63.

82. Turk Z, Vauhnik R, Micetic-Turk D. Prevalence of nonspecific low back pain in schoolchildren in North-Eastern Slovenia. Coll Antropol. 2011;35(4):1031-5.

83. van Gent C, Dols JJ, de Rover CM, Hira Sing RA, de Vet HC. The weight of schoolbags and the occurrence of neck, shoulder, and back pain in young adolescents. Spine (Phila Pa 1976). 2003:28(9):916-21.

84. Viry P, Creveuil C, Marcelli C. Nonspecific back pain in children. A search for associated factors in 14-year-old schoolchildren. Rev Rhum Engl Ed. 1999; 66(7-9):381-8

85. Watson KD, Papageorgiou AC, Jones GT, Taylor S, Symmons DP, Silman AJ, et al. Low back pain in schoolchildren: the role of mechanical and psychosocial factors. Arch Dis Child. 2003;88(1):12-7.

86. Wedderkopp N, Andersen LB, Froberg K, Leboeuf-Yde C. Back pain reporting in young girls appears to be puberty-related. BMC Musculoskelet Disord. 2005:6:52.

87. Wedderkopp N, Leboeuf-Yde C, Andersen LB, Froberg K, Hansen HS. Back pain reporting pattern in a Danish population-based sample of children and adolescents. Spine (Phila Pa 1976). 2001;26(17):1879-83.

88. Wirth B, Humphreys BK. Pain characteristics of adolescent spinal pain. BMC Pediatr. 2015;15:42.

89. Wirth B, Knecht C, Humphreys K. Spine day 2012: spinal pain in Swiss school children- epidemiology and risk factors. BMC Pediatr. 2013;13:159.

90. Yao W, Luo C, Ai F, Chen Q. Risk factors for nonspecific low-back pain in Chinese adolescents: a case-control study. Pain Med. 2012;13(5):658-64. 
91. Briggs AM, Smith AJ, Straker LM, Bragge P. Thoracic spine pain in the general population: prevalence, incidence and associated factors in children, adolescents and adults. A systematic review. BMC Musculoskelet Disord. 2009:10:77.

92. Kamper SJ, Yamato TP, Williams CM. The prevalence, risk factors, prognosis and treatment for back pain in children and adolescents: an overview of systematic reviews. Best Pract Res Clin Rheumatol. 2016;30(6):1021-36.

93. Louw QA, Morris LD, Grimmer-Somers K. The prevalence of low back pain in Africa: a systematic review. BMC Musculoskelet Disord. 2007;8:105.

94. Calvo-Munoz I, Kovacs FM, Roque M, Gago Fernandez I, Seco Calvo J. Risk factors for low Back pain in childhood and adolescence. A systematic review. Clin J Pain. 2017;34(5):468-84.

95. Lardon A, Leboeuf-Yde C, Le Scanff C, Wedderkopp N. Is puberty a risk factor for back pain in the young? A systematic critical literature review. Chiropr Man Therap. 2014:22(1):27.

96. Dario AB, Kamper SJ, O’Keeffe M, Zadro J, Lee H, Wolfenden L, et al. Family history of pain and risk of musculoskeletal pain in children and adolescents: a systematic review and meta-analysis. Pain. 2019;00:1-10.

97. Jeffries $L$, Milanese SF, Grimmer-Somers KA. Epidemiology of adolescent spinal pain: a systematic overview of the research literature. Spine. 2007; 32(23):2630-7.

98. Hartvigsen J, Nielsen J, Kyvik KO, Fejer R, Vach W, lachine I, et al. Heritability of spinal pain and consequences of spinal pain: a comprehensive genetic epidemiologic analysis using a population-based sample of 15,328 twins ages 20-71 years. Arthritis Care Res. 2009;61(10):1343-51.

99. Ferreira PH, Beckenkamp P, Maher CG, Hopper JL, Ferreira ML. Nature or nurture in low back pain? Results of a systematic review of studies based on twin samples. Eur J Pain. 2013;17(7):957-71.

100. Meeuwisse WH, Tyreman H, Hagel B, Emery C. A dynamic model of etiology in sport injury: the recursive nature of risk and causation. Clin J Sport Med. 2007;17(3):215-9.

101. Ardakani EM, Leboeuf-Yde C, Walker BF. Failure to define low back pain as a disease or an episode renders research on causality unsuitable: results of a systematic review. Chiropr Man Therap. 2018;26(1):1.

\section{Publisher's Note}

Springer Nature remains neutral with regard to jurisdictional claims in published maps and institutional affiliations.

Ready to submit your research? Choose BMC and benefit from:

- fast, convenient online submission

- thorough peer review by experienced researchers in your field

- rapid publication on acceptance

- support for research data, including large and complex data types

- gold Open Access which fosters wider collaboration and increased citations

- maximum visibility for your research: over $100 \mathrm{M}$ website views per year

At $\mathrm{BMC}$, research is always in progress.

Learn more biomedcentral.com/submissions 